\title{
IDENTIFIKASI KEMAMPUAN BERHITUNG PADA MATERI PENJUMLAHAN BERDASARKAN COUNTING ON DI SD MUHAMMADIYAH 2 TARAKAN
}

\author{
Eka Widyawati ${ }^{1}$, Hariaty Hamid ${ }^{2}$, Setia Widia Rahayu ${ }^{3}$ \\ ${ }_{1,2,3}$ Jurusan Pendidikan Matematika, Universitas Borneo Tarakan \\ 1Eka.adel48@gmail.com \\ 2hariaty.pmat@gmail.com \\ ${ }^{3}$ Setia.widiaayu@yahoo.com
}

\begin{abstract}
This study aims to identify the level of students' mathematical arithmetic skills in solving problems in the summing material based on counting on in class II of SD Negeri 018 Tarakan. The method used is a quantitative approach to the type of descriptive explanation. The results of the study were obtained from the students' numeracy ability test results based on the mathematics numeracy ability category of students in the high and medium categories. The problems used to identify the ability to count scheme are three problems, namely problems related to counting on, counting all, then counting on and counting all. The results of students' math skills based on the counting on scheme were obtained through interviews with 25 research subjects. Problem 1 was solved by students with a counting scheme of 10 students (40\%), Problem 2 was solved by students with a counting scheme of 1 student (4\%). Problem 3 is solved by students with a counting on scheme of 2 students $(8 \%)$.
\end{abstract}

Keywords: ability to count, and counting on.

\begin{abstract}
Abstrak
Penelitian ini bertujuan untuk mengidentifikasi tingkat kemampuan berhitung matematika siswa dalam menyelesaikan soal pada materi penjumlahan berdasarkan counting on di kelas II SD Negeri 018 Tarakan. Metode yang digunakan adalah pendekatan kuantitatif jenis eksplanasi deskriptif. Hasil penelitian yang diperoleh dari hasil tes kemampuan berhitung siswa berdasarkan kategori kemampuan berhitung matematika siswa berada pada kategori tinggi dan sedang. Masalah yang digunakan untuk mengidentifikasi skema kemampuan berhitung adalah tiga soal, yaitu masalah yang terkait counting on, counting all, kemudian counting on dan counting all. Hasil kemampuan berhitung matematika siswa berdasarkan skema counting on diperoleh melalui wawancara terhadap 25 subjek penelitian. Masalah 1 diselesaikan siswa dengan skema counting on sebanyak 10 siswa (40\%), Masalah 2 diselesaikan siswa dengan skema counting on sebanyak 1 siswa (4\%). Masalah 3 diselesaikan siswa dengan skema counting on sebanyak 2 siswa (8\%).
\end{abstract}

Kata kunci: kemampuan berhitung, dan counting on.

Matematika merupakan salah satu mata pelajaran yang diajarkan secara terus-menerus di setiap jenjang pendidikan, bahkan matematika telah diperkenalkan di tingkat paling dasar yaitu Taman Kanak-Kanak. Matematika sebagai ilmu dasar dari pengembangan sains (basic of science) akan sangat berguna dalam kehidupan. Materi awal yang diperkenalkan untuk siswa kelas 2 SD di awal pembelajaran yaitu bilangan. Bilangan sebagai komposisi dari angka-angka adalah pencapaian konseptual yang sangat penting bagi pemahaman konsep-konsep dan prosedur matematika pada materi penjumlahan (Resnick, 1983; Thompson, 2008). Bilangan sebagai materi prasyarat yang harus dikuasai di semua materi pelajaran matematika. Kemampuan siswa terhadap materi bilangan bulat khususnya pada materi penjumlahan menjadi dasar bagi siswa Sekolah Dasar untuk mempelajari materi-materi berikutnya. Apabila pengetahuan 
Berdasarkan hasil wawancara dengan seorang guru matematika di SD Muhammadiyah 2 Tarakan, diperoleh informasi bahwa siswa kelas 2 mengenal angka-angka dengan baik namun dalam proses perhitungan khususnya penjumlahan masih terdapat siswa yang melakukan kesalahan dan bimbingan pada saat membaca soal. Hasil analisis masalah tersebut oleh penulis diduga adalah guru hanya berfokus pada penggunaan algoritma saja sehingga siswa belum memahami membaca soal cerita, konsep bilangan dan operasinya dengan baik.

Menurut Watson and Matson (2006) matematika sebagai Constructive Activity yang berfokus pada pembentukan aspek matematis sendiri oleh peserta didik. Oleh karena itu, pemahaman tentang suatu materi matematika membutuhkan pondasi yang kuat yaitu dengan memahami konsep yang merupakan syarat utama. Hal ini melingkupi konsep penalaran, konsep pemahaman simbol, dan penguasaan konsep keabstrakan dan generalisasi. Prosedur yang dapat digunakan siswa untuk menghitung penjumlahan ada dua yaitu counting all (hitung semua) dan counting on (hitung lanjut) (Maclellan, 2007). Siswa akan menggunakan salah satu prosedur counting all, counting on, atau bahkan bisa terjadi transisi skema berpikir siswa dari skema counting all ke skema counting on. Transisi skema berpikir siswa dari skema counting all ke skema counting on sesuai dengan hasil penelitian oleh Baroody (1987) \& Fuson (1982). Prosedur yang dilakukan siswa tentu saja bergantung pada pengetahuan, pemikiran, dan pengalaman siswa terhadap suatu bilangan itu sendiri.

Prosedur perhitungan melalui hitung lanjut (counting on) dan hitung semua (counting all) sudah diteliti oleh beberapa peneliti. Namun, penelitian yang membahas tentang counting on dan counting all di Indonesia masih sedikit ditemukan dan terbilang penelitian baru. Guru-guru di sekolah dasar pun masih asing mendengar istilah tersebut, walaupun secara sadar ataupun tidak siswa-siswa di sekolah dasar telah melakukan prosedur tersebut. Dalam penelitian ini dianalisis prosedur perhitungan siswa melalui hitung lanjut (counting on). Dari soal yang diberikan, dapat dilihat bagaimana prosedur yang digunakan siswa dalam menyelesaikan soal yang diberikan.

Potensi kognitif seseorang tercermin dalam kemampuannya menyelesaikan tugas-tugas yang menyangkut pemahaman dan penalaran. Witherington (dalam Sujiono, 2009:1.16) mengemukakan bahwa kognitif adalah pikiran, kognitif, (kecerdasan pikiran) melalui pikiran dapat digunakan dengan cepat dan tepat untuk mengatasi suatu situasi untuk memecahkan masalah. Bruner mengemukakan tentang teori kognitif yaitu segala ilmu dapat diajarkan pada semua anak dari semua usia, asal materinya benar-benar sesuai. Ada 3 tingkat perkembangan menurut Bruner yaitu:

\section{Enactiva}

Dalam tahap ini penyajian yang dilakukan melalui tindakan anak secara langsung terlihat dalam memanipulasi (mengotak-atik objek)

2. Iconic

Dalam tahap ini kegiatan penyajian dilakukan berdasarkan pada pikiran internal dimana pengetahuan disajikan melalui serangkaian gambar-gambar atau grafik yang dilakukan anak, berhubungan dengan mental yang merupakan gambaran dari objek-objek yang dimanipulasinya. 


\section{Simbol}

Dalam tahap ini bahasa adalah pola dasar simbolik, anak memanipulasi simbol-simbol atau lambang-lambang objek tertentu

Berdasarkan tingkat perkembangan Brunner Siswa SD sudah dapat memanipulasi simbolsimbol secara langsung dan tidak ada kaitannya dengan objek-objek. Siswa SD melalui pemahamannya telah mencapai transisi dari tahap ekonik ke tahap simbolik. Agar proses mempelajari sesuatu pengetahuan atau kemampuan berlangsung secara optimal, kemampuan dapat diintrenalisasi dalam struktur kognitif orang yang bersangkutan.

Dalam penelitian ini dianalisis prosedur perhitungan siswa melalui hitung lanjut (counting on). Counting on merupakan struktur berpikir (skema) yang digunakan seorang siswa untuk memecahkan masalah penjumlahan dari masing-masing item dalam dua bilangan yang dihitung secara terpisah. Dalam menghitung penjumlahan dari $5+4=9$ maka terlebih dulu siswa harus memahami yaitu bilangan 5 (lima) sebagai kuantitas pertama dan 4 (empat) sebagai kuantitas kedua, untuk mendapatkan hasil penjumlahan yaitu 9 siswa memulai perhitungan memulai dari bilangan pada kuantitas pertama dan menghitung lanjut untuk kuantitas kedua (misal: 5; 6-7-8-9) (Tzur \& Lambert, 2011).

Menghitung dengan menggunakan Counting On bertujuan untuk melakukan perhitungan pada tiap item bilangan yang ada dalam kuantitas kedua dan secara bersamaan menghitung bilangan pada kuantitas pertama. Faktor-faktor yang mempengaruhi konseptualisasi bilangan dalam mempengaruhi konseptualisasi bilangan dalam memecahkan masalah perhitungan antara lain:

(1) Siswa menggunakan counting on untuk menyelesaikan permasalahan satu digit dengan bilangan yang lebih besar, contoh $9+4$,

(2) Siswa akan menggunakan hitung lanjut (counting on) untuk bilangan yang salah satu dari kedua kuantitas tersebut belum diketahui.

Dari soal yang diberikan, dapat dilihat bagaimana prosedur yang digunakan siswa dalam menyelesaikan soal yang diberikan.

\section{METODE}

Penelitian ini merupakan penelitian kuantitatif dengan pendekatan eksplanasi deskriptif. Penelitian ini bertujuan untuk memaparkan tingkat kemampuan berhitung matematika siswa pada materi penjumlahan berdasarkan prosedur counting on. Sampel penelitian adalah 25 orang. Selanjutnya 25 orang siswa tersebut menyelesaikan soal yang diberikan. Masalah yang diberikan untuk mengidentifikasi skema kemampuan berhitung adalah tiga soal, yaitu masalah yang terkait counting on, counting all, kemudian counting on dan counting all. Setelah siswa menyelesaikan soal yang diberikan. Selanjutnya peneliti melakukan wawancara terhadap subjek penelitian untuk mengelompokkan kemampuan berhitung matematika siswa berdasarkan skema yang digunakan. Data yang diperoleh dari hasil tes siswa mengerjakan soal dan wawancara akan digunakan untuk 
memperoleh informasi mengenai kemampuan berhitung matematika siswa berdasarkan skema counting on.

\section{HASIL DAN PEMBAHASAN}

Berdasarkan hasil tes siswa diperoleh tingkat kemampuan berhitung matematika siswa berdasarkan tabel berikut.

Tabel 1. Kelompok Kategori Kemampuan Berhitung Matematika Siswa

\begin{tabular}{ccccc}
\hline No & Interval & Kategori & Jumlah Siswa & Persentase \\
\hline 1 & $75<x$ & Tinggi & 10 & $40 \%$ \\
2 & $58<x \leq 75$ & Sedang & 10 & $40 \%$ \\
3 & $x \leq 58$ & Rendah & 5 & $20 \%$ \\
\hline & Jumlah & & 25 & $100 \%$
\end{tabular}

Berdasarkan tabel 1 kategori kemampuan berhitung matematika siswa berada pada kategori tinggi dan sedang. Dari keseluruhan sampel yang diteliti yaitu 25 siswa, sebanyak 10 siswa memiliki nilai diatas 75, dan 10 siswa memiliki nilai diatas 58, serta 5 siswa memiliki nilai dibawah 58. Dengan demikian kemampuan berhitung matematika siswa SD kelas II dalam kategori tinggi dan sedang.

Tes Essay yang telah diselesaikan siswa menunjukkan hampir seluruh siswa paham dan bisa menggunakan kemampuan berhitungnya. Dengan hasil rata-rata kemampuan berhitung 72,8 dari 25 siswa maka sudah terlihat jelas bahwa kemampuan berhitung siswa sangat tinggi. Siswa dapat mengerjakan dengan benar, walaupun ada beberapa siswa yang masih kurang tepat dalam perhitungannya.

Selanjutnya hasil kemampuan berhitung matematika siswa dikelompokkan berdasarkan counting on yang diperoleh melalui wawancara terhadap 25 subjek penelitian. Berikut hasil pengelompokkan kemampuan berhitung matematika siswa setiap skema didasarkan pada counting on pada tabel 3.2 sebagai berikut.

Tabel 2. Skema yang digunakan siswa untuk setiap item soal

\begin{tabular}{cccc}
\hline \multicolumn{4}{c}{ Item Soal } \\
Skema & $\mathbf{1}$ & $\mathbf{2}$ & $\mathbf{3}$ \\
\hline Counting On & $10(40 \%)$ & $1(4 \%)$ & $2(8 \%)$
\end{tabular}

Berdasarkan tabel 2 subjek yang menyelesaikan soal 1 menggunakan prosedur counting on berjumlah 10 orang, subjek yang menyelesaikan soal 2 menggunakan prosedur counting on berjumlah 1 orang, subjek yang menyelesaikan soal 3 menggunakan prosedur counting on berjumlah 1 orang. Pencapaian kemampuan berhitung siswa dalam menyelesaikan soal operasi hitung penjumlahan telah dipahami dan dikuasai oleh siswa dilihat dari kategori kemampuan berhitung yang disajikan pada tabel 3.1 bahwa siswa berada pada kategori tinggi dan sedang. Berdasarkan analisa konseptual siswa dalam menyelesaikan operasi hitung bilangan bulat dan juga berdasarkan wawancara menunjukkan paling banyak siswa menggunakan strategi counting on pada saat menyelesaikan soal 1 maupun soal 3 terjadi pada siswa berkemampuan tinggi hal ini sejalan dengan penelitian wulandari (2014) 
menyatakan bahwa proses berpikir kemampuan tinggi terjadi cukup baik dan konsep-konsep yang tersimpan dalam memori jangka panjang subjek kemampuan tinggi yang dibutuhkan dalam memecahkan masalah juga cukup banyak dan baik.

Subjek AM menyelesaikan soal 1, subjek paham terhadap penjumlahan dua bilangan yang lebih dari 5 namun terdapat keraguan saat membuat perhitungan menggunakan counting on sehingga subjek menggunakan strategi counting all. Subjek dengan kemampuan rendah ditemukan tidak dapat mengerti perintah soal, sehingga perlu arahan pada saat menyelesaikan soal hal ini bersesuaian dengan penelitian Canobi, Reeve, dan Pattison (1998) yang menyatakan anak-anak yang gagal untuk mengenali hubungan masalah, ketidakpekaan terhadap hubungan dapat menyebabkan ketergantungan pada tidak efisiennya strategi pemecahan masalah yang pada gilirannya dapat membatasi peluang siswa untuk membangun pemahaman konseptual.

\section{KESIMPULAN}

1. Kategori kemampuan berhitung matematika siswa berada pada kategori tinggi dan sedang. Dari 25 subjek penelitian

2. Siswa dengan konsep penjumlahan menggunakan prosedur counting on yang menyelesaikan soal 1 menggunakan prosedur counting on berjumlah 10 orang, subjek yang menyelesaikan soal 2 menggunakan prosedur counting on berjumlah 1 orang, subjek yang menyelesaikan soal 3 menggunakan prosedur counting on berjumlah 1 orang.

\section{DAFTAR PUSTAKA}

Baroody, A. J. (1987). The Education. Vol 18, 141-157.

Canobi, K.H., Reeve, R.A.,\& Pattison, P.E. (1998). The role of conceptual understanding in children's addition problem solving. Developmental Psychology, 34(5): 882-91.

Fuson, K.C. (1982). An Analysis of The Counting On Solution Procedure in Addition. pp 67-80) Development of Counting Strategies for Single-Digit Addition. Journal for Research in Mathematics.

Maclellan, Effie. (1995). Counting all, counting on, counting up, counting down: The role of counting in learning to add and subtract. International Journal of Primary, Elmentary and Early Years Education. Vol 23-Issue 3 (3-31).

Resnick, L.B. (1983). A developmental theory of number understanding. Ginsburg (pp.109-151)

Sujiono, N.Y. (2009). Metode Pengembangan Kognitif. Jakarta: Universitas Terbuka.

Tzur, R \& Lambert, M. A. 2011. Journal for Research in Mathematics Education. Vol 42, 418-450

Watson and Mason. (2006). Seeing an exercise as a single Mathematical Object: Using Variation To Structure Sense-Making. Mathematical Thinking and Learning. 8(2) p91-111.

Wulandari. (2012). Proses Berpikir Siswa dalam Pemecahan Masalah Berdasarkan Counting On. Ethos (Jurnal Penelitian dan Pengabdian Masyarakat: 21-28). 